\title{
The Importance of Visual Reading for the Interpretation of a Literary Text ${ }^{1}$
}

JANJA Batič ${ }^{\star 2}$ AND DRAgicA Haramija ${ }^{3}$

$\approx$ In this paper, the two authors showcase the results of a research survey on the role of illustrations in the interpretation of literary texts. The survey sample included students of primary education and preschool education, who were given the poem Učenjak (Scholar) by Niko Grafenauer and asked to answer questions regarding the character's personality and appearance, the literary space, and other factors. The first group of interviewees was given the poem illustrated by Lidija Osterc and the other the same poem illustrated by Marjan Manček. The results showed that the illustration had a significant impact on the message conveyed by the poem, particularly when the illustrator added the context by representing the character's environment (which was not explicitly given in the text). Furthermore, the results showed the need for the comprehensive reading of an illustrated text, given that it is the interaction between the verbal and the visual that provides vital information necessary for the reader to understand the message of the dedicated literary work.

Keywords: picture books, illustrations, comprehensive reading (interaction), Grafenauer, Manček, Osterc, Pedenjped

1 The paper was written as a part of a research project CRP 2015-2016, Nu. V6-1506, entitled Cultural and systemic factors of reading literacy in Slovenia.

2 *Corresponding Author. University of Maribor, Faculty of Education, Slovenia; janja.batic@um.si

3 University of Maribor, Faculty of Education and Faculty of Arts, Slovenia 


\section{Introduction}

The time and space dedicated to visual arts in primary school education in Slovenia are frequently restricted to the subject currently referred to as "Visual Arts" though the point of the subject is, in fact, art education. Notwithstanding the unfortunate name of the subject, we need to reconsider the role of visual arts, not only with regard to teaching the Visual Arts subject, where the relation is clearly established but more so with regard to teaching subject matter from other subject areas. Visual arts may be a good starting point for effective teaching practices in other subject areas, which has been excellently illustrated by Karen Hosack Jansen (2014) through several practical cases. She makes artwork the basis of an interdisciplinary art project, describing the process of developing the project concept as follows:

When you have decided which visual arts knowledge and skills you want to teach in a project, including which transferable key skills, you need to think about which work or works of art would make a suitable stimulus (as long as high-quality reproductions can be sourced) and which other subject areas might be taught under the umbrella of a thematic approach (2014, p. 76).

This is one of the possible ways of how to use or better include visual arts in various subject areas.

We frequently tend to forget or neglect the fact that pupils encounter works of art each time they discuss an illustrated literary text in their Slovenian class (it may be a picture book, an illustrated novel, etc.). The criteria on which language teachers select literary works to be discussed are often exclusively literary, and the analysis of the works is conducted at the level of the text. Hence, illustrations are regarded merely as highlights and additions rather than constituent parts of the book discussed. Since we are continuously exposed to a great deal of visual imagery-with visual information having become the main source of information-we need to consider whether such an analysis of illustrated literary works is still appropriate. Perry Nodelman elaborated on the relationship between text and pictures back in 1988, giving the two an equal position.

Because they communicate different kinds of information, and because they work together by limiting each other's meanings, words and pictures necessarily have a combative relationship; their complementarity is a matter of opposites completing each other by virtue of their differences. As a result, the relationships between pictures and texts in picture 
books tend to be ironic: each speaks about matters on which the other is silent (Nodelman, 1988, p. 221).

Authors of various surveys (e.g. Sipe, 1998; Nikolajeva, 2003) focused on the text-image relationship most frequently when analysing picture books that are a special type of multimodal books. According to Haramija and Batič, picture books comprise "three key ingredients: text, illustrations, and the contentform relationship between the text and the illustration" (2013, p. 23). What is particularly interesting in terms of the analysis is the verbal relationship or the interaction. Sipe notes that "[...] the relationship between two types of text - the verbal and the visual texts - is complicated and subtle" (1998, p. 97). He further observes that their relationship is synergistic, as "[...] the total effect depends not only on the union of the text and illustrations but also on the perceived interactions or transactions between these two parts" (Sipe, 1998, pp. 98-99). Nikolajeva (2003) identifies three types of interactions: symmetrical interaction (the text and the images tell the same story); complementary interaction (words and pictures fill gaps and missing information); enhancing interaction (pictures underline or say something more than the text or vice versa). The enhanced interaction can develop in two directions: when the said difference becomes significant, a counterpoint dynamic may develop (the meaning is beyond the scope of either level of communication alone), while an extreme form is contradictory interaction (pictures and words communicate ambiguous messages that require a higher level of mental effort from the reader). We can see the respective forms of interaction also with relation to a single illustration and corresponding text. The issue of the relationship between image and text is particularly interesting when we read a poem with a dedicated illustration. Most commonly, the illustrations in poetry collections are placed on the page facing the corresponding poem. The second option is to have the text integrated into the illustration itself. A picture book may include only one poem with each part of the poem being incorporated into its own illustration, such as in in Where Do Dreams Go (2008) by Lila Prap. The relationship between the visual and the verbal in the latter is so close that only comprehensive reading allows proper interpretation of the poem-the literary character is not mentioned in the text, only the illustration reveals that it is a boy. Furthermore, the illustration outlines the literary space, subject reality, and other elements.

Illustrations can, in fact, change the way we understand the text. They most frequently provide additional information on literary time, literary characters, mood, space and characters, subject reality, and events not mentioned in the text (Haramija \& Batič, 2013, pp. 262-264). Illustrators frequently define 
literary time by including in their illustration a clock, a calendar or seasonal references. In the cultures in which texts are read from left to right, people tend to translate the left-right placement to a before-after timeline of the events. This is particularly evident if the same literary character has been depicted in an illustration twice (e.g. two-sided illustrations), yet we do not understand that as there being two identical characters but rather as a representation of the timeline of the events that include movement. Nikolajeva notes (2003, p. 15):

[...] the most often used and the most successful device to express movement within a single picture is what art critics call simultaneous succession [...]. It implies a sequence of images, most often of a figure, depicting moments that are disjunctive in time but perceived as belonging together, in an unequivocal order. The change occurring in each subsequent image is supposed to indicate the flow of time between it and the preceding one.

When Nikolajeva refers to "each subsequent image" (2003, p. 15), we understand the subsequent image being the one placed to the right of the preceding one. What is placed on the left takes place before and what is on the right occurs after that.

Literary characters in shorter texts are normally given names but no details, so it is on the illustrator to define their appearance. The same thing applies to space. Nikolajeva points out: "While words can only describe space, pictures can actually show it, doing so more effectively and often more efficiently. [...] The verbal narrator forces the reader to 'see' certain details of the setting, while ignoring others. Visual representation of the setting is 'non-narrated' and therefore non-manipulative" (2003, p. 11). At the same time, the illustrator directs the reader's/viewer's attention by changing the perspective and the focus. An interesting "conflict" appears when the illustrator highlights the happening that is not explicitly mentioned in the text and puts the main event in the background. We can find several examples of this in the picture book Juri Muri $v$ Afriki (Juri Muri in Africa) by Tone Pavček and Damijan Stepančič (2012). It is a book about a boy who disliked washing himself, in which the illustrator depicted the main event, in several of the illustrations, merely as a part of a larger picture. How the reader will understand or interpret an illustration also depends on their understanding of symbols, signs, and context. Reader's experience plays a crucial role in the interpretation of the context as well.

The above elements first and foremost refer to what has been represented but also to how it has been represented (e.g. movement implied by the placement of visual elements within the composition). The reader's knowledge of 
the basics of art theory (visual art elements, art composition methods, etc.) and various art techniques and their expressive potential is a fundamental prerequisite for the comprehensive reading of an illustrated text. Jane Doonan points out, "[O]nce children have been told and shown how lines and shapes and colours are able to refer to ideas and feelings, they can explore the dimension beyond what is literally represented" $(1993$, p. 8). This is only possible providing we teach the viewers (pupils) to become visually sensitive individuals that will interpret an illustration through what has been represented and how, including which visual art devices have been used.

The theoretical starting point was developed based on studying picture books that included a large number of illustrations of a dedicated text. The question we focused on was: what was the narrative power of a single illustration of a specific poem, or in other words, could a single illustration influence the interpretation of the corresponding poem and in what way?

\section{Methodology}

A survey, ${ }^{4}$ the goal of which was to identify how an illustration can change the meaning of a poem, was conducted in June 2014. The convenience sample $(n=301)$ included students of the Faculty of Education at the University of Maribor, Slovenia, majoring in preschool education (146 students or 48.5 per cent), and primary education ( 155 students or 51.5 per cent). During the survey, the respective students were enrolled in the first year of the 1st cycle (19.3 per cent), the second year of the 1st cycle (37.2 per cent), and third year of the 1st cycle (43.5 per cent). The sample included 279 female (92.7 per cent) and 22 male (7.3 per cent) participants. The participation in the survey was voluntary and anonymous. The students were divided into two groups and shown the illustrated poem Učenjak (Scholar) by Niko Grafenauer, which was projected on canvas. The first group (56.1 per cent of the students) was shown the poem illustrated by Lidija Osterc (hereinafter referred to as Pedenjped $A$ ), while the other group (43.9 per cent) was shown the same poem illustrated by Marjan Manček (hereinafter Pedenjped $B$ ). The students were then asked to fill in a questionnaire comprising open-ended questions (e.g. What is Pedenjped like? What kind of books does he read? etc.). Their responses were then grouped into categories, analysing the collected data with SPSS software,

4 The research survey is part of an extensive survey conducted among the students of the Faculty of Education (primary education, preschool education, and art education programmes) and of the Faculty of Arts (Slovenian language and literature), both at the University of Maribor. This discourse includes only the results of the survey among the students of primary and preschool education, as their curriculum includes subjects related to literature and artistic expression. 
using descriptive statistics (frequency) and inferential statistics (chi-square test).

The criteria for the selection of the poem were literary (Niko Grafenauer is a renowned Slovenian poet) as well as artistic (the poem was illustrated by two prominent Slovenian illustrators: Lidija Osterc and Marjan Manček). Niko Grafenauer (b. 1940), an editor and a translator, who has been a member of the Slovenian Academy of Sciences and Arts since 2003, writes for both adults and children. His poetry is of particular importance within children's literature, though he has written two prose works for children as well. ${ }^{5}$ Grafenauer has received a number of awards for his work, including the prestigious Prešeren Lifetime Achievement Award (1997) and Levstik Lifetime Achievement Award (2007). In her introduction to Slovenian children's literature, Marjana Kobe points out:

[i]n the mid-196os Niko Grafenauer (Pedenjped, 1966) took from the source of Slovenia's artistic poetry-making for children going back to Fran Levstik, announcing a boom in poetics deriving from the theory of play as a "symbol of the world". [...] At the same time, Niko Grafenauer and Saša Vegri opened new horizons for children's poetry by poetising existential questions (1996, p. 4).

In his article on contemporary Slovenian children's poetry (2006, p. 273), Igor Saksida substantiates Grafenauer's prime position within children's poetry during the time of modernism. ${ }^{6}$ Furthermore, Saksida elaborates his idea in the article entitled “Methodology for Interpretation of Slovenian Children's Literature", pointing out that:

Grafenauer's (1975) essay, "Igra v pesništvu za otroke" (Play in poetry for children) remains one of the most significant contributions to the understanding of linguistic procedures in quality children's poetry and in poetry in general. The author describes the development of children's poetry from its beginnings, with Levstik to the present. He identifies

5 The most important children's works by Niko Grafenauer include Secrets (Skrivnosti), 2012 and other editions; Frog Radio Station (Žabja radijska postaja), 2011; Three Geese and a Gander (Troje gosk in en gosak), 2011; Littleman Has a Tail Again (Pedenjped ima spet rep), 2010; Pointy and the Hallofly (Špicmožic in Halomuha), 2009; Free Entry into the Littleman Fairy Tale (V Pedenjpravljico prost vstop), 2003; Riddles (Uganke), 2001; When the Head Swims above the Clouds (Kadar glava nad oblaki plava), 2000; Mahaiana and Other Fairy Tales about Littlish (Mahajana in druge pravljice o Majhnici), 1990; Littlish (Majhnica), 1987; Old Ljubljana (Stara Ljubljana), 1983; Locomotive, Locomotive (Lokomotiva, lokomotiva), 1981; Skyscrapers, Sit Down (Nebotičniki, sedite), 1980); Carosaur (Avtozaver), 1976.

6 Saksida notes that "[a] esthetic play is fundamental in modernist children's poetry, though not merely as the theme of the poem-it incorporates the following characteristics: play as a way of depicting the textual reality, that is, through illogical word combinations; inventing new words and violation of orthography rules; breakaway from depiction of human figure (in particular child) to equivocal descriptions of objects, body parts, and existential notions" (2006, p. 271). 
(linguistic) play (or linguistic interpretation) as the determining factor in quality (aesthetically mature) poetry, which is the equal of literature for adults (Haramija \& Saksida, 2013, p. 185).

The poetics principles he adheres to in writing his own poetry are the same principles he recognizes as the absolute quality marker in other children's poets. His strong attachment to the poetic tradition of Fran Levstik and Oton Župančič, the pioneers of Slovenian children's poetry at the turn of the $19^{\text {th }}$ century, is also evident in the poetics of Grafenauer's poetry collection Pedenjped. The first edition of this lyrical children's poetry from 1966 included illustrations by Lidija Osterc and was soon followed by a revised edition in 1969 and a picture book with selected poems and illustrations by Marjan Manček in 1979. Between 1966 and 2014, 17 editions were published (including reprints), each time including a different set of poems about Pedenjped. ${ }^{7}$ Pedenjped is a commonly recognized literary character among Slovenian children, which has remained popular throughout the nearly fifty years since its first appearance. In terms of its theme, the collection is homogenous, with a child's (i.e. Pedenjped's) perspective reflecting the daily life in the child's home environment, which is mostly associated with safety and play. Grafenauer has succeeded-and that is the main quality of all poems about Pedenjped - to introduce, through a child's perspective and emotions, the world of a contemporary child living in abundance and peace. The author himself proves this to be true by stating:

Through Pedenjped I wanted above all to get close to a child's way of seeing things and events that they encounter daily and simultaneously merge that with my own childhood experiences and impressions emerging within me as I observe children today, so as to make the personality of this character as likeable as possible (Grafenauer, 1969, p. 67).

The author has succeeded in that, so this poetic pattern can be created still today-the author has been writing poems about this child next door for fifty years. In the first poem (entitled Pedenjped) the boy is described in detail: he is wearing a "pedenjsrajčka" (little shirt) and "pedenjhlače" (little pants), his hair is tousled, and he has dimples in his cheeks. The themes of the subsequent poems are about him putting on his clothes, washing, feeding, playing, and performing other activities. The titles of the collections indicate the morphological

7 Poems about Pedenjped have been published (between 1966 and 2013) seventeen times, of which 15 collections entitled Pedenjped included different sets of poems, while two collections were given new titles, namely, Littleman Has a Tail Again (Pedenjped ima spet rep), and Littleman of his Word (Možbeseda Pedenjped). 
structure including the word "pedenj" which is used to describe something that is little (shirt, trousers, shoes), something that belongs to him (formed from a noun: mother, father; formed from a verb: help), or both (kingdom, pictures, speed train, bed), implying not only ownership but also function, e.g. pedenjslika (little picture) is not only a small picture but also a picture made by Pedenjped. ${ }^{9}$ The poet uses interesting idioms (e.g. biti mož beseda (to be a man of one's word), napokati se kakor boben (be full as a tick)), and onomatopoetic expressions (e.g. in his poem entitled Uspavanka (Lullaby) he uses the words "trilili", "tralala", in the poem Brzovlak (Fast train) he uses "uuu", while his most onomatopoetic poem is entitled Glasbenik (Musician) using words, such as "svirili", "svirilili", "svirilaja" and combinations thereof). All his poems are lyrical poems with a conventional structure with four-line stanzas. The poet uses alternate rhyme or rhyming couplets, along with enjambment and personification (e.g. spoon is in a hurry) in nearly every poem. The respective poem is structurally similar to others.

\section{Scholar}

Pedenjped loves browsing through

big heaps of books of various kinds.

He reads aloud and nods his head

at notions from all sorts of minds.

Slouched o'er books at all times,

each page he studies with intent.

His noggin bobbing from insights,

he props his head up with his hands.

At home, he doesn't mind the jumble,

with 'la-la-la' his time he passes.

But if over a word he stumbles

at once he dons his reading glasses.

(Grafenauer, 1966, p. 23; translation by Dušan Rabrenovič)

8 According to the Slovenian Normative Guide (2001, p. 1086), the word "pédenj" is defined as a prefix in a compound word meaning little, e.g. pédenjčlôvek is a little man.

9 In the poem Brzovlak (Fast train) it is clear throughout the poem that it is Pedenjped who is in fact a little speed train (pedenjbrzovlak): "po vseh štirih v noč sopiha [...] Če pa je hudo zaspan,/ spet postane Pedenjped." (Grafenauer, 2011, p. 22) (translation: on all fours puffing into the night [...] When he gets terribly sleepy,/ he is Pedenjped again.; Author's Note) 
Lidija Osterc ${ }^{10}$ (Image 1, Pedenjped A) complemented the poem with an illustration of a boy with bushy hair, round glasses, shorts, striped socks and pointy little shoes. His shorts and socks resemble the fashion from the first half of the twentieth century. He is standing in an upright position, holding in his hand the book titled ABECEDA (Alphabet) which is turned upside down. There is no representation of space, and the illustration is placed right next to the text. The boy's head is facing the left side. Judging by his body proportions, we can assume that it is a schoolboy rather than a preschool child. The boy in the picture appears to be "reading" or viewing the book with interest, though the letters on the cover being turned upside down indicate that he cannot actually read. The drawing by Lidija Osterc is in black and white, printed on a toned paper. The title of the poem is white, while the text is black. The use of achromatic colours arouses the feeling of aloofness and seriousness. However, the illustration does not provide any information on what "jumble" (the phrase in the Slovenian language is 'hišni hrup' which literally means "domestic noise"; author's note) is supposed to be.

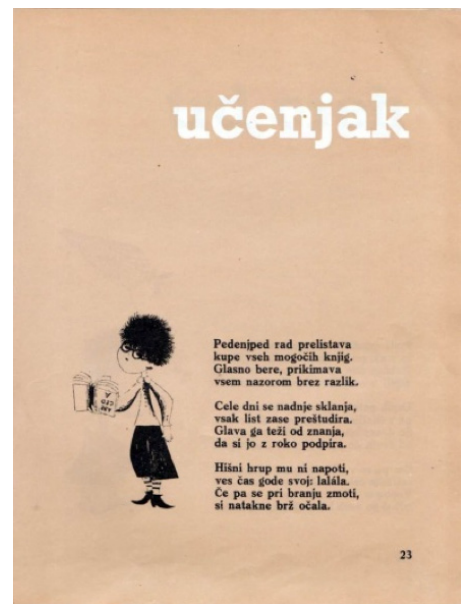

Image 1. Niko Grafenauer and Lidija Osterc: Pedenjped. Ljubljana: Mladinska knjiga, 1966, p. 23

10 Lidija Osterc (1928-2006) has a degree from the Academy of Fine Arts and Design, and works as a painter and an illustrator. She has received three Levstik Awards for her illustrations: in 1964 for the illustrations in the picture book Hišica iz kock (House of Building Blocks) by Ela Peroci, in 1966 for the illustrations in Slovenian editions of fairy tales by the Brothers Grimm, namely, Lonček, kuhaj! (The Magic Porridge Pot) and Sneguljčica (Snow White) and the illustrations in Desetnica (The Tenth Daughter) by Frane Milcinski, and in 1969 for the illustrations in Laponske pripovedi (Tales from Lapland) by Robert Crottet, Strašni lovec Bumbum (Bumbum the Terrifying Hunter) by Tone Pavček, and Očala tete Bajavaje (Aunt Bajavaja’s Specs) by Ela Peroci. 


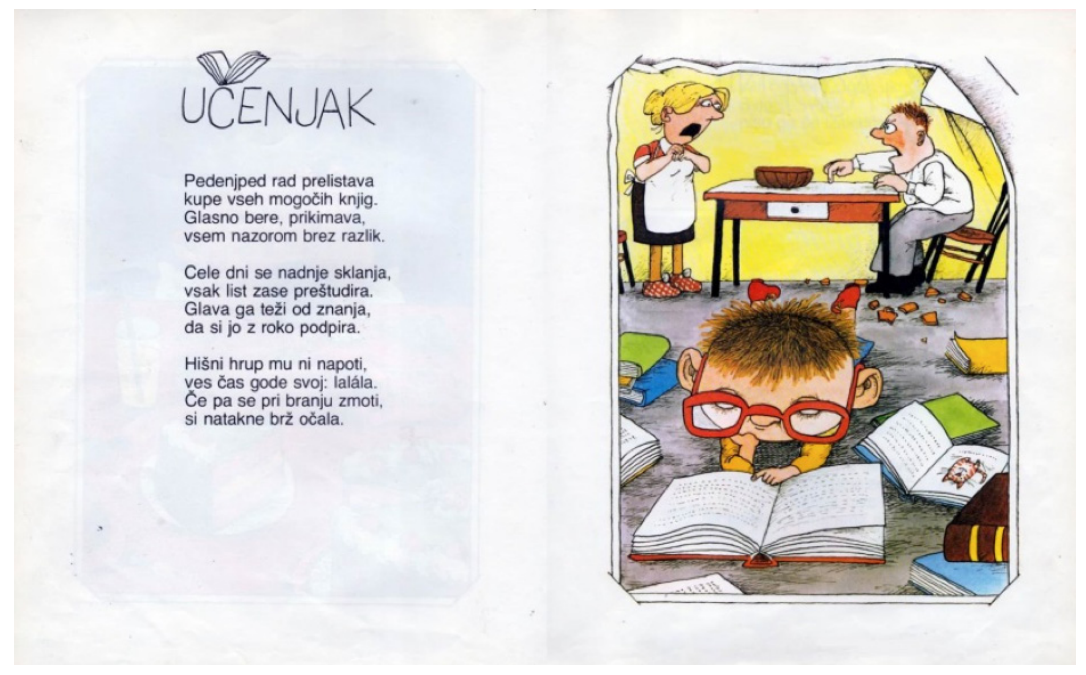

Image 2. Niko Grafenauer and Marjan Manček: Pedenjped. Ljubljana:

Mladinska knjiga, 1979, no pagination

In his illustration, Marjan Manček ${ }^{11}$ decided to place Pedenjped, a boy with a big head (his body proportions suggest he is a young, possibly preschool child), big red glasses, tousled brown hair, blue trousers, and red shoes, in the forefront. There is a thick open book before him. He is supporting his head with his right hand while his left index finger is pointing at the text. He is lying amid piles of books. In one of the open books, we can see a picture of a cat. The scene is depicted from below. In the background, we can see a table and two people. Standing on the left is a woman with open mouth, corners turned down, and hands joined tightly in front. On the right there is an angry-looking man tapping the table with his right index finger and there are shards under the table. Marjan Manček made a coloured drawing with yellow, green, blue, and red being the most prominent colours. The illustration has been "framed", so it looks like a photo in an album. The wrinkled top edge and a dog-ear on the top right corner imply the temporal distance of the represented scene, that is, a past event, the memory of which has been documented in a photo album. In addition, the "worn out" part of the illustration intensifies the tension of the scene happening behind Pedenjped. The illustration appears separately on the

11 Marjan Manček (1948) is a free-lance artist with a degree in English and History from the Faculty of Arts, University of Ljubljana, working mostly as a cartoonist (e.g. comic book Hribci (The Hillies)), illustrator, and film animator. He has received several awards for his work, one of the most prominent being the 2007 Levstik Award for lifetime achievement in illustration. In 1977, he received a Levstik Award for his illustrations of Kozlovska sodba v Višnji gori (The Goat Trial in Višnja Gora) by Josip Jurčič, and a Hinko Smrekar Award in 2009. 
right-hand page while the poem is placed on the opposite page. The caron of the letter "Č" in the title is replaced by a drawing of an open book. The illustration by Manček accentuates the child's world (worm'seye view, strong chromatic colours) and the significance of the environment (family environment, the presence of books), while also depicting the "jumble" (parents' quarrelling or, more precisely, an angry, aggressive father and a scared mother).

\section{Results and interpretation}

The first thing we were interested in was to see how the students perceived Pedenjped's character. The most frequently recurring students' statements were "he likes to read or thumb through books" (45.5 per cent), "he is sophisticated, intelligent, learned" (34.9 per cent), "he is inquisitive and eager to learn" (27.9 per cent), "he likes to learn" (15.6 per cent), "he is playful, naughty, bratty" (14.6 per cent), and "he is a diligent and obedient child" (13.0 per cent). When asked about what kind of books Pedenjped liked to read, most students noted that he read "all kinds of books or various books" (82.4 per cent). Only a minor share of the students (24.3 per cent) specified or described the books in more detail (e.g. picture books, encyclopaedias, thick books). To the question as to whether Pedenjped actually read or not, nearly a third of the students (31.2 per cent) noted that Pedenjped did read, while others thought he did not read but rather pretended to read.

The analysis of the answers showed there was no statistically significant difference between the students who observed Illustration A (by Lidija Osterc) and those observing Illustration B (by Marjan Manček).

In describing his appearance, the most frequently observed feature was Pedenjped's eyewear, as 68.4 per cent of the students noted that he wore eyeglasses. Nearly half of the students described his haircut and/or hair length (47.5 per cent). Furthermore, 38.9 per cent of the interviewees described Pedenjped as a child or a young boy. Other references to physical features included his hair colour (17.9 per cent), size of his eyeglasses (11.3 per cent), details about his personal hygiene (referred to as messy and poor) (8.3 per cent), trouser details (8.0 per cent), shirt details (8.o per cent), colour of his eyeglasses ( 7.6 per cent), ears (protruding and/or large) (6.6 per cent), his size (6.o per cent of the students described Pedenjped as being a big boy), shoes details ( 5.6 per cent), his figure (slim) (5.3 per cent), and socks details (4.7 per cent). The results were analysed in view of the illustrations observed (A or B), which showed that none of the students in the group analysing the illustration by Lidija Osterc described the colour of Pedenjped's eyeglasses. In contrast, none of the students observing the 
illustration by Marjan Manček characterized Pedenjped as being a big boy nor did they mention his socks. Statistically significant differences were also identified in some of the other questions (Table 1).

Table 1. Description of appearance

\begin{tabular}{|c|c|c|c|c|c|c|c|c|c|}
\hline & & \multicolumn{6}{|c|}{ Illustration } & \multirow{2}{*}{\multicolumn{2}{|c|}{$\chi^{2}$ - test }} \\
\hline & & \multicolumn{2}{|c|}{ A - L. Osterc } & \multicolumn{2}{|c|}{ B - M. Manček } & \multicolumn{2}{|c|}{ combined } & & \\
\hline & & $f$ & $f \%$ & $f$ & $f \%$ & $f$ & $\mathrm{f} \%$ & $\chi^{2}$ & $P$ \\
\hline \multirow{2}{*}{$\begin{array}{l}\text { Describing the size } \\
\text { of his eyeglasses }\end{array}$} & YES & 3 & 1.8 & 31 & 23.5 & 34 & 11.3 & \multirow{2}{*}{34.861} & \multirow{2}{*}{0.000} \\
\hline & NO & 166 & 98.2 & 101 & 76.5 & 267 & 88.7 & & \\
\hline \multirow{2}{*}{$\begin{array}{l}\text { Describing the co- } \\
\text { lour of his eyeglasses } \\
\text { (red) }\end{array}$} & YES & 0 & 0.0 & 23 & 17.4 & 23 & 7.6 & \multirow{2}{*}{31.883} & \multirow{2}{*}{0.000} \\
\hline & NO & 166 & 100.0 & 109 & 82.6 & 278 & 92.4 & & \\
\hline \multirow{2}{*}{$\begin{array}{l}\text { Describing his hair } \\
\text { length or hairstyle }\end{array}$} & YES & 96 & 56.8 & 47 & 35.6 & 143 & 47.5 & \multirow{2}{*}{13.355} & \multirow{2}{*}{0.000} \\
\hline & NO & 73 & 43.2 & 85 & 64.4 & 158 & 52.5 & & \\
\hline \multirow{2}{*}{$\begin{array}{l}\text { Describing the hair } \\
\text { colour }\end{array}$} & YES & 18 & 10.7 & 36 & 27.3 & 54 & 17.9 & \multirow{2}{*}{13.090} & \multirow{2}{*}{0.000} \\
\hline & NO & 151 & 89.3 & 96 & 72.7 & 247 & 82.1 & & \\
\hline \multirow{2}{*}{ Small boy, a child } & YES & 46 & 27.2 & 71 & 53.8 & 117 & 38.9 & \multirow{2}{*}{22.018} & \multirow{2}{*}{0.000} \\
\hline & NO & 123 & 72.8 & 61 & 46.2 & 184 & 61.1 & & \\
\hline \multirow{2}{*}{ Big boy } & YES & 18 & 10.7 & 0 & 0.0 & 18 & 6.0 & \multirow{2}{*}{14.953} & \multirow{2}{*}{0.000} \\
\hline & NO & 151 & 89.3 & 132 & 100.0 & 283 & 94.0 & & \\
\hline \multirow{2}{*}{$\begin{array}{l}\text { Large or protruding } \\
\text { ears }\end{array}$} & YES & 3 & 1.8 & 17 & 12.9 & 20 & 6.6 & \multirow{2}{*}{14.731} & \multirow{2}{*}{0.000} \\
\hline & NO & 166 & 98.2 & 115 & 87.1 & 281 & 93.4 & & \\
\hline \multirow{2}{*}{ Trousers details } & YES & 22 & 13.0 & 2 & 1.5 & 24 & 8.0 & \multirow{2}{*}{13.364} & \multirow{2}{*}{0.000} \\
\hline & NO & 147 & 87.0 & 130 & 98.5 & 277 & 92.0 & & \\
\hline \multirow{2}{*}{ Socks details } & YES & 14 & 8.3 & 0 & 0.0 & 14 & 4.7 & \multirow{2}{*}{11.468} & \multirow{2}{*}{0.001} \\
\hline & NO & 155 & 91.7 & 132 & 100.0 & 287 & 95.3 & & \\
\hline & YES & 19 & 11.2 & 6 & 4.5 & 25 & 8.3 & & \\
\hline Messy, poor mygiene & NO & 150 & 88.8 & 126 & 95.5 & 276 & 91.7 & 4.500 & 0.031 \\
\hline & YES & 16 & 9.5 & 0 & 0.0 & 16 & 5.3 & & \\
\hline 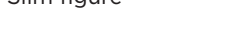 & NO & 153 & 90.5 & 132 & 100.0 & 285 & 94.7 & (1) & 0.000 \\
\hline
\end{tabular}

Furthermore, we asked the students about their interpretation of the word 'jumble'. Their answers fell into two groups. According to the first group, the cause of the jumble was the boy's parents quarrelling, while the second group of answers considered the jumble to be a result of different sounds in the apartment (e.g. noises caused by dishes, pets). The difference between the answers from either group was statistically significant (Table 2). 
Table 2. Interpretation of the word 'jumble'

\begin{tabular}{|c|c|c|c|c|c|c|c|c|c|}
\hline & & \multicolumn{6}{|c|}{ Illustration } & \multirow{2}{*}{\multicolumn{2}{|c|}{$\chi^{2}-$ test }} \\
\hline & & \multicolumn{2}{|c|}{ A - L. Osterc } & \multicolumn{2}{|c|}{ B - M. Manček } & \multicolumn{2}{|c|}{ combined } & & \\
\hline & & $f$ & $\mathrm{f} \%$ & $f$ & $\mathrm{f} \%$ & $f$ & $f \%$ & $\chi^{2}$ & $\mathrm{P}$ \\
\hline \multirow{2}{*}{$\begin{array}{l}\text { Jumble as a result of } \\
\text { parents quarrelling }\end{array}$} & YES & 14 & 8.3 & 92 & 69.7 & 106 & 35.2 & \multirow{2}{*}{122.520} & \multirow{2}{*}{0.000} \\
\hline & NO & 155 & 91.7 & 40 & 30.3 & 195 & 64.8 & & \\
\hline \multirow{2}{*}{$\begin{array}{l}\text { Sounds in the apart- } \\
\text { ment (dishes, pets, } \\
\text { etc.) }\end{array}$} & YES & 156 & 92.3 & 66 & 50.0 & 222 & 73.8 & \multirow{2}{*}{68.531} & \multirow{2}{*}{0.000} \\
\hline & NO & 13 & 7.7 & 66 & 50.0 & 79 & 26.2 & & \\
\hline
\end{tabular}

We further inquired after the environment in which Pedenjped lived. The students most frequently described it as an environment in which one could not have some peace and quiet while the least frequent answer was that Pedenjped retreated to his own world due to the family situation. The difference between the answers from either group was statistically significant (Table 3 ).

Table 3. Description of the environment

\begin{tabular}{|c|c|c|c|c|c|c|c|c|c|}
\hline & & \multicolumn{6}{|c|}{ Illustration } & \multirow{2}{*}{\multicolumn{2}{|c|}{$\chi^{2}-$ test }} \\
\hline & & \multicolumn{2}{|c|}{ A - L. Osterc } & \multicolumn{2}{|c|}{ B - M. Manček } & \multicolumn{2}{|c|}{ combined } & & \\
\hline & & $f$ & $\mathrm{f} \%$ & $f$ & $\mathrm{f} \%$ & $f$ & $\mathrm{f} \%$ & $\chi^{2}$ & $P$ \\
\hline \multirow{2}{*}{$\begin{array}{l}\text { Environment charac- } \\
\text { terized by conflicts } \\
\text { between parents. }\end{array}$} & YES & 5 & 3.0 & 39 & 29.5 & 44 & 14.6 & \multirow{2}{*}{41.974} & \multirow{2}{*}{0.000} \\
\hline & NO & 164 & 97.0 & 93 & 70.5 & 257 & 85.4 & & \\
\hline \multirow{2}{*}{ Unsettled environment. } & YES & 6 & 3.6 & 41 & 31.1 & 47 & 15.6 & \multirow{2}{*}{42.568} & \multirow{2}{*}{0.000} \\
\hline & NO & 163 & 96.4 & 91 & 68.9 & 254 & 84.4 & & \\
\hline \multirow{2}{*}{$\begin{array}{l}\text { Environment with no } \\
\text { peace and quiet. }\end{array}$} & YES & 50 & 29.6 & 59 & 44.7 & 109 & 36.2 & \multirow{2}{*}{7.326} & \multirow{2}{*}{0.007} \\
\hline & NO & 119 & 70.4 & 73 & 55.3 & 192 & 63.8 & & \\
\hline \multirow{2}{*}{$\begin{array}{l}\text { Environment character- } \\
\text { ized by poor relation- } \\
\text { ships, no parental love. }\end{array}$} & YES & 14 & 8.3 & 37 & 28.0 & 51 & 16.9 & \multirow{2}{*}{20.535} & \multirow{2}{*}{0.000} \\
\hline & NO & 155 & 91.7 & 95 & 72.0 & 250 & 83.1 & & \\
\hline \multirow{2}{*}{$\begin{array}{l}\text { Friendly and stimulating } \\
\text { environment. }\end{array}$} & YES & 61 & 36.1 & 0 & 0.0 & 61 & 20.3 & \multirow{2}{*}{59.755} & \multirow{2}{*}{0.000} \\
\hline & NO & 108 & 63.9 & 132 & 100.0 & 240 & 79.7 & & \\
\hline \multirow{2}{*}{$\begin{array}{l}\text { Pedenjped's own world } \\
\text { he retreats to due to } \\
\text { parents fighting. }\end{array}$} & YES & 2 & 1.2 & 17 & 8.3 & 19 & 6.3 & \multirow{2}{*}{17.142} & \multirow{2}{*}{0.000} \\
\hline & NO & 167 & 98.8 & 115 & 123.7 & 282 & 93.7 & & \\
\hline
\end{tabular}




\section{Discussion}

One of the conclusions that can be made based on our survey results is that in describing Pedenjped's character, the interviewees drew mostly from the text of the poem rather than from the illustrations, as there were no statistically significant differences between the answers of the two groups of interviewees. Naturally, we cannot disregard other poems on Pedenjped, as the appearance and the features ascribed to him by the survey participants have appeared throughout the poet's entire oeuvre on Pedenjped, as illustrated by Marjan Manček. Pedenjped's physical appearance is defined through his clothes and shoes, tousled hair, protruding ears, dimples in his cheeks. His favourite foods include potica (traditional Slovenian nut roll), sweets, and ice-cream. What leads us to assume that he is a really young boy is his behaviour: he picks his nose, he cannot wipe his nose by himself, he plays imaginary games, he is angry at his own reflection in the mirror (he does not recognize himself), he is drawing on the walls, plays the flute out of tune. As a result, his brattiness and playfulness may sometimes appear to be disturbing, so Pedenjped gets the worst of it when he is, for example, sent to bed by his father for having drawn on the walls, his tummy aches because he has eaten too much candy, or is pricked by a cactus sting while watering it carelessly. Grafenauer intentionally highlights the characteristics, activities, and appearance we normally attribute to a small child.

Furthermore, the survey results showed that the visual component, i.e., the illustrations, played a key role in describing the physical appearance. There was a statistically significant difference between the descriptions delivered by the two groups of interviewees, based on the illustration they were given to observe. Students analysing the illustration of Pedenjped by Manček (B) noticed the boy's big red glasses more frequently than students from the other group, the reason being that they are a prominent feature in the illustration that can be noted immediately (their disproportionate size compared to the head, spatial plan, angle of viewing). Over a half of the students observing the illustration by Manček noted that Pedenjped was a small boy or a child. Their answer is hardly unexpected, considering the head-to-body ratio that resembles bodily proportions of a child. Furthermore, their answer makes even more sense when we consider that the students in question have known Pedenjped from other poems and illustrations. Over one tenth of the students noticed Pedenjped's large protruding ears, which Grafenauer had introduced in his poem titled Pedenjped, where he noted that they looked like two uncles angry with each other, whimsically sticking out (1966, p. 6). Grafenauer's Pedenjped is considered to be a canonical character in Slovenian children's literature, which is first 
introduced to Slovenian children in preschool, or at the latest by the end of the first triennial of the primary school education during which children focus mostly on poems about Pedenjped..$^{12}$ The interviewed sample included students aged between 19 and 21, which means that they must have discussed the poems about Pedenjped with illustrations by Manček, as they were included in the then school readers. ${ }^{13}$

The character of Pedenjped as created by Lidija Osterc is very much different from Manček's Pedenjped, so it is understandable that students noticed different things when describing the former. They described the boy's hairstyle, trousers, and socks. The illustration features the whole body standing in an upright position, so it is easier for the viewer to notice the details. At the same time, Pedenjped is a character that is rather unusual and special from the contemporary point of view, as his clothes belong to the times when the poem was written (i.e. the past). Further, we can notice that the illustrator has created a stylized character whose features also appear in her other illustrations and are key ingredients of her visual language (e.g. Naša bela mačica (Our White Kitten) by Srečko Kosovel, 1969). Only a small portion of students characterized Pedenjped as messy, and they noticed his slim figure as well. None of them wrote that Pedenjped was a child. In fact, one tenth claimed that he was a big boy.

The most notable difference between the observations by the two groups regards Pedenjped's age. Pedenjped by Marjan Manček is considered a child by 53.5 per cent of the interviewees and big boy by merely 27.2 per cent of the interviewees. Pedenjped by Lidija is considered a big boy by 10.7 per cent of the interviewees, though none of the students observing the respective illustration characterized him as a child or a young boy (o.o per cent). Moreover, since the size adjectives (i.e. big boy) also imply the character's age, the observed difference is of crucial importance for the poem's interpretation. The majority of the interviewees believe that Pedenjped does not in fact read but merely pretends to be reading. Furthermore, there is a huge difference between a big boy that cannot read and a little child that cannot read. Based on the activities indicated throughout the poem-thumbing through books, his 'noggin bobbing' (set phrase) from all the knowledge, him putting on his glasses when he stumbles over a word-we are made to assume that he does not understand

12 The curriculum for the Slovenian Language (http://www.mizs.gov.si/fileadmin/mizs.gov.si/ pageuploads/podrocje/os/prenovljeni_UN/UN_slovenscina_OS.pdf, pp. 21-22, accessed on 15.3.2015) suggests the following poems to be discussed in the second grade of primary school: Dvojcka, Sladkosned, Trd oreh. As regards the acquisition of knowledge pertaining to literary science, Niko Grafenauer has been listed as the author to be discussed when dealing with children's poetry.

13 It has been established that Slovenian libraries hold more copies of the picture book with Manček's illustrations than both issues of the book illustrated by Lidija Osterc. 
the cause-and-effect relationship entirely. If he is unable to read something, his eyeglasses will not help either, and the same applies to the read text as well.

An analysis of survey results showed that the environment in which the character is set changes the context of the poem lyrics, thus affecting the interpretation of the poem. There was, in fact, a noticeable difference between the answers provided by either group of the students, depending on which illustration they were given to observe. Pedenjped by Lidija Osterc lives in a friendly and stimulating environment, which may at times be loud, but the jumble from the poem is mainly associated with noises in the apartments, such as clanking of the dishes, pet sounds and noises, and alike. Pedenjped as seen by Marjan Manček, in contrast, lives (listed according to the frequency of students' answers): in an environment with no peace and quiet, in an unsettled environment, in an environment characterized by parental conflicts, in an environment characterized by poor relationships without parental love. In this version, the students-interviewees interpreted the jumble from the lyrics as parent's quarrelling and noises from the apartment.

The interpretation of the poem and the cause-and-effect relations are given a new dimension when taking into consideration the visual component, i.e. the illustration. What affects the interpretation the most is the perceived age of the character and the environment he is set in. When the character is surrounded by an empty space, our understanding of the environment is based largely on the information derived from reading the text. The interpretation of the 'jumble' from the poem depends on the reader's experience (familiarity with the notion and their own experience). When the character is set in an environment that is not described in the text, it becomes a vital part of the context, which we cannot neglect when interpreting the poem. The illustration by Lidija Osterc does not affect the interpretation of the poem, as the message remains the same regardless of whether we read with the illustration in front of us or without it. Marjan Manček, in contrast, introduced the environment next to the character, which definitely affects the interpretation of the poem. The artist represented a family environment in his illustration, leading the reader to believe that jumble, in fact, implies quarrelling. The physical appearance of Pedenjped as represented by Manček has definitely become an inseparable part of the poet's character; in other words, it has become in itself a generally recognized feature of the canonical literary character.

The conclusion we can draw from the survey is that when reading an illustrated poem, we need to employ an integrated approach. In other words, we need to treat the visual and the verbal as equally important. That is particularly important when the interaction between the text and the image is such that the 
latter complements the former. Frank Serafini (2011, p. 346) has developed a set of questions that teachers can use to guide their pupils through the analysis of the visual structures in a multimodal text, such as: Which are the dominant colours? What effect do they have on you as a reader? What is the artist trying to get you to look at through leading lines, colours, contrast, gestures, and lighting?

During their studies, Slovenian students of primary education and preschool education acquire sufficient knowledge of literature (literary theory and literary history basics; children's literature forms, types and genres; reading canonical and contemporary works in children's literature and their analysis and interpretation) and visual expression (art theory basics, theoretical and practical knowledge of visual art techniques and their expressive properties). It is, therefore, safe to say that they are equipped with sufficient knowledge for the comprehensive reading of picture books and illustrated books. However, problems may arise in interdisciplinary integration. Hence, the question is how to prepare students (i.e. prospective teachers) to be able to think beyond disciplines and plan as well as introduce the comprehensive reading of illustrated texts. Their students or pupils will see the interaction between text and illustration only if they will be properly guided by their teacher by means of questions that will encourage them to explore, to search for answers in both text and illustration, to discern the expressive possibilities of art techniques and materials, to be sensitive to composition, and to provide information-based answers (each statement is supported by information from the text and/or illustration). Developing this type of reading will surely contribute to the improved visual literacy of children. According to Vasquez, Troutman and Comer, visual literacy is 'the ability to (a) read and interpret a visual image and (b) communicate information using visual representation' (2010, p. 2). A comprehensive reading of illustrated texts is a sound way to improve the visual literacy of students and pupils, which is why further research into comprehensive reading is absolutely imperative.

\section{References}

Doonan, J. (1993). Looking at pictures in picture books. Lockwood, Station Road, Woodchester:

Thimble Press.

Grafenauer, N. (1966). Pedenjped. Illustrated by Lidija Osterc. Ljubljana: Mladinska knjiga.

Grafenauer, N. (1979). Pedenjped. Illustrated by Marjan Manček. Ljubljana: Mladinska knjiga

(Collection Velike slikanice).

Haramija, D., \& Batič, J. (2013). Poetika slikanice. Murska Sobota: Franc-Franc.

Haramija, D., \& Saksida, I. (2013). Metodologija interpretacije mladinske književnosti na

Slovenskem. Slavistična revija, 61(1), 181-193. 
Hosack Janes, K. (2014). Using the Visual Arts for Cross-curricular Teaching and Learning: Imagiantive ideas for primary school. London and New York: Routledge, Taylor\&Francis Group.

Kobe, M. (1996). Slovenska mladinska književnost. Slovenska mladinska književnost in ilustracija. Ljubljana: Slovenska sekcija IBBY. 3-7.

Kosovel, S. (1969). Naša bela mačica. Illustrated by Lidija Osterc. Ljubljana: Mladinska knjiga (Collection Čebelica).

Nikolajeva, M. (2003). Verbalno in vizualno: slikanica kot medij. Otrok in knjiga, 58, 5-26.

Nodelman, P. (1988). Words about pictures. Athens and London: The University of Georgia Press.

Pavček, T. (2012). Juri Muri v Afriki: o fantu, ki se ni maral umivati. Illustrated by Damijan Stepančič. Dob pri Domžalah: Miš.

Prap, L. (2008). Kam gredo sanje. Ljubljana: Mladinska knjiga (Collection Žlabudron).

Saksida, I. (2006). Sodobna slovenska mladinska poezija. In M. Hladnik (Ed.), Preseganje meje: zbornik Slavističnega društva Slovenije 17 (pp. 267-279). Ljubljana: Slavistično društvo Slovenije. Serafini, F. (2011). Expanding Perspectives for Comprehending Visual Images in Multimodal Texts. Journal of Adolescent \& Adult Literacy, 54(5), 342-350. Available at Academic Search Complete (accessed 18 July 2012).

Sipe, L. R. (1998). How Picture Books Work: A Semiotically Framed Theory of text-Picture Relationships. Children's Literature in Education, 29(2), 97-108. Available at SpringerLink (accessed 15 July 2012).

Vasquez, J. A., Troutman, F., \& Comer, M. W. (2010). Developing Visual Literacy in Science, K-8. Arlington, VA: NSTA Press, National Science teachers Association. Available at eBook Academic Collection Trail (accessed 8 April 2014).

\section{Biographical note}

JANJA BATIČ has a BA from the Faculty of Education at the University of Maribor, and an MA and a PhD from the Faculty of Education at the University of Ljubljana. She is an assistant professor for art education didactics at the Faculty of Education at the University of Maribor, Slovenia. Her research area includes art education didactics as well as planning and execution of architectural art assignments. The author has been collaborating with Dragica Haramija in studying the phenomenon of comprehensive reading of picture books as multimodal texts.

Dragica Haramija has a BA from the Faculty of Education at the University of Maribor, Slovenia, an MA from the Faculty of Arts at the University of Zagreb, Croatia, and a PhD from the Faculty of Arts at the University of Ljubljana, Slovenia. She is full professor of literature. She is a lecturer at the Faculty 
of Arts and the Faculty of Education. Her basic field of work is children's literature: theories of genre in children's prose and the history of Slovenian children's literature. She is a researcher who has so far published seven monographs. 